\title{
THE LIFE OF A YOUNG PHYSICIAN
}

The only statue which stands in the courtyard of the Medical Faculty of Paris is that of a young man who neither attended nor taught in a formal medical school. The figure was erected in 1857 to honour the memory of Marie-François-Xavier Bichat, who had died fifty-five years earlier. Along with many young Frenchmen during the revolutionary years, Bichat obtained his medical education as an apprentice to senior men. For a time, he assisted medical practitioners who served with the French armies in the field. He went to Paris in 1794, less than a year after the revolutionary tribunal had decreed the abolution of all university faculties. The lack of a formal education did not hinder Bichat particularly. Though he was only thirty years old when he died, he had accomplished a formidable quantity of work which earned him a considerable fame, at least in Paris. Within the next few years, his reputation spread far throughout Europe and even into North America.

Bichat was known first as a spokesman for a vitalist theory of the life sciences and second as the creator of the tissue theory of anatomy. As a vitalist, he argued eloquently that life sciences are different from physical sciences because living matter is fundamentally different in its properties and its behaviour from that which is inert. His arguments influenced physiological theory well into the nineteenth century. When François Magendie and Claude Bernard argued in the nineteenth century that physiologists erred in assuming that there were two distinct natural realms, they were speaking largely to Bichat's position. Bichat located what he called "vital properties", which he believed to be unique to living matter, in the body's tissues. He isolated twenty-one tissues in the body and he showed that they unite in various combinations to produce its organs and structures much as chemical elements produce compounds. This tissue theory of anatomy became the basis of the science of histology and it has often been judged to be Bichat's most important contribution to medical and physiological theory.

During his brief career as a physician, physiologist, and anatomist, Bichat taught a considerable number of students. They apparently held him in warm regard as a man who could inspire them with his own enthusiasm for his subject. His associates at Paris's largest hospital, the Hôtel-Dieu, and his colleagues in various professional societies described Bichat as a modest, warm man of a gentle and open nature. Such affirmations and recollections about the dead are common enough, of course. Bichat's funeral, however, suggests that his various biographers were not merely offering token tributes. It was a moving occasion, fifty carriages draped in black accompanying the body in the procession. On hearing of Bichat's death, the First Consul Napoleon Bonaparte instructed his Minister of the Interior to place a marble monument in the Hôtel-Dieu to honour Bichat and his teacher, the surgeon Pierre Desault. Since then, in their inimitable way, the French have continued to pay tribute to Bichat's memory with numerous plaques, paintings, statues, busts, engravings, odes, eulogies, and biographies. He has been the subject of innumerable student theses. In Paris, a street 


\section{The life of a young physician}

and hospital are named after Bichat; he is represented on the pediment of the Pantheon; the Faculty of Medicine has a statue of him inside the building as well as one in the courtyard.

Xavier Bichat was born in 1771, the first of four children, in a small fishing village called Thoirette-en-Bas near Lyons. ${ }^{1}$ This was the family home of his parents, who were officially classified as bourgeois. The boy was brought up nearby in a small town called Poncin, where his father Jean-Baptiste practised medicine, having received his medical degree from the University of Montpellier in 1769. In the middle of the eighteenth century, most of the medical faculty of that ancient medical school adhered to a vitalist theory of living matter. One of the elder Bichat's teachers had been the vitalist Paul-Joseph Barthez, whose influence and prestige in Montpellier were unparalleled in the eighteenth century. Barthez' ideas about the nature of the life sciences and their distinction from physical ones were to influence Xavier Bichat greatly in subsequent years. It may be that his father's work sparked an interest in the life sciences in his first-born son. Some years after Xavier's death, his younger brother César described him as having had a precocious interest in science. By the age of seven, Xavier was purportedly practising dissection on the cats and dogs of the neighbourhood. He liked to hunt, but only when he could dissect his trophies. I expect that those enthusiastic recollections were merely exaggerations to suit an occasion. If not, it is possible that today Bichat would have been sent to reform school.

At the age of eleven, like his father before him, Bichat was sent to the Jesuit Collège de Nantua near Lyons. His parents withdrew him from there in August 1790 because they did not share the enthusiasm of the townsfolk and even of the school officials for the Revolution, which had begun the previous year. From Nantua, Bichat went to the Seminary of Saint Irénée in Lyons, where one of his uncles was Superior. The Revolution and France's wars with her neighbours were henceforth to intrude themselves frequently into the young man's life. Had the political upheaval not occurred, Bichat

\footnotetext{
1 There are many papers and theses which outline Bichat's life and work. The most recent and accurate account is by Maurice Genty, 'Xavier Bichat (1771-1802)', in Pierre Huard (editor), Biographies médicales et scientifiques, Paris, Dacosta, 1972. An earlier one by the same author is 'Bichat et son temps', La médecine internationale illustrée, serialized monthly from July 1934 to September 1935. It deals with Bichat's family, his personal and professional life, and even with the lives of his major associates. His contributions to medicine and physiology are not treated in any detail. Genty also published a six-page pamphlet, 'Quelques documents sur la famille et la maison natale de Bichat', Bull. Soc. Hist. Med., 1933, 28: nos. 3-4. He found the first record of the Bichat family in the 1682 parochial archives of Thoirette. Jacques Coquerelle had published a short book Xavier Bichat, (1771-1802), Paris, A. Maloine, 1902, the first part of which is a profusion of details about the family, its genealogy, personal and professional letters, and a brief survey of Bichat's army and medical careers. Coquerelle did painstaking archival work in Thoirette, the Collège de Nantua, and in Paris. A large part of his book is given over to reproducing eulogies and odes delivered in Bichat's honour. A diverse collection of material was put together by Prof. Raphael Blanchard in Centenaire de la mort de Xavier Bichat, Paris, Librairie Scientifique et Littéraire, 1903. It contains two biographical speeches which Blanchard delivered on the occasion of the centenary celebrations, one at Bichat's tomb and the other before his house in the rue des Carmes. A section of 'Documents inedits concernant Xavier Bichat' contains letters and military and professional documents. Finally, 'Documents artistiques relatifs à Xavier Bichat' gives a list of portraits, plaques, busts, statues, and medals that honour him. A few unique and personal features are found in a biographical sketch by Bichat's cousin Mathieu-François Buisson, 'Précis historique sur Marie-François-Xavier Bichat', Traité d'anatomie descriptive, 5 vols., Paris, Brosson, Gabon, 1802, vol. 3, pp. vii-xxviii. Unless otherwise indicated, the biographical material contained in Chapter $\mathrm{I}$ is taken from these various sources.
} 


\section{Xavier Bichat}

would have studied anatomy and surgery as an apprentice and then perhaps have taken medicine at Montpellier. He might even have returned to a medical practice in the pastoral countryside of the Rhône Valley. It was not to be, however.

The chief hospital in a French city or town is called the Hôtel-Dieu. Bichat began courses in anatomy and surgery at the Hôtel-Dieu in Lyons in 1791. It was only in the eighteenth century that the status of surgery had been raised sufficiently to separate surgeons from their long-standing association with the company of barbers. In spite of vociferous protests, especially from the powerful Medical Faculty of Paris, which traditionally blocked virtually all innovation, a Royal Academy of Surgery was created in 1731 and empowered to grant a Master of Surgery degree. It was part of an attempt to put surgeons on a level with the considerably more prestigious physicians, who alone among medical practitioners were university trained. In the 1790s, most students still learned surgical skills by attaching themselves as apprentices to a master. Since 1788, the Chief Surgeon at the Hôtel-Dieu in Lyons was Marc-Antoine Petit. For two years, he had been a student of Pierre-Joseph Desault, the Chief Surgeon of the Hôtel-Dieu in Paris between 1785 and 1795, and the pre-eminent surgeon in France. ${ }^{2}$ Desault was to become Bichat's master in Paris in 1794. Europe's hospitals at the end of the eighteenth century were filthy, vermin-ridden structures in which at least as much disease was contracted as cured. Lacking ventilation, privacy, and even minimal hygiene, the institutions mixed sufferers from smallpox and syphilis among expectant mothers. People scheduled for surgery listened to the screams of those undergoing it. Mortality was high. In the Hôtel-Dieu of Paris it was about one in every three patients; that of Lyons seems to have been somewhat better, having modernized to the point where each of its possible 400 patients could have his own bed. In Paris, as many as four patients might occupy the same bed, especially when the hospital was crowded in unhealthy seasons and during epidemics. ${ }^{3}$

The year that Bichat began his surgical training was a difficult one for all the learned professions. The institutions of the former regime were increasingly under attack as élitist structures which must be purged of their privileged membership or destroyed altogether. The theory and outlines of a new educational system were being widely discussed, but it was to be years before a new structure replaced the old one. In the meantime, the members of the National Assembly were effectively creating a kind of educational vacuum as they set about destroying the symbols of former privilege. In a flurry of egalitarian sentiment, the National Assembly abolished the master's degree in medicine as well as all examinations for medical degrees in February 1791. In March, it decreed that anyone paying a fee could be licensed to practise medicine and surgery without examination. At about the same time, some members were purged from the Academy of Medicine.

Such steps exacerbated the health crisis that followed France's declaration of war

\footnotetext{
2 The growth of the professional status of surgery in France, and its role in the new medicine of postrevolutionary France are discussed in Toby Gelfand, Professionalizing modern medicine: Paris surgeons and medical science and institutions in the eighteenth century, Westport, Conn., and London, Greenwood Press, 1980.

${ }^{3}$ This is discussed by David M. Vess in Medical revolution in France, 1789-1796, Gainesville, University Press of Florida, 1975, pp.10-39. The Hôtel-Dieu in Paris is described by Charles Coulton Gillispie, Science and polity in France at the end of the old regime, Princeton University Press, 1980, pp. 244-256.
} 


\section{The life of a young physician}

on Austria and Prussia in April 1792. The Legislative Assembly authorized the drafting of medical personnel and the requisitioning of private houses, chateaux, convents, and churches for military hospitals. ${ }^{4}$ One such was established almost immediately in the former Seminary of Saint Irénée. Bichat had to interrupt his studies in November 1792 in order to serve as a chirurgien-surnumeraire in his former school, a kind of junior assistant to the qualified surgeons.

In February 1793, the Vendée rose in revolt in reaction to conscription, the Revolution, and the rigours of war in general. The revolt grew into a civil war which threatened to tear France apart. To deal with the combined internal and external crises, the National Assembly in April 1793 created the Committee of Public Safety headed by Georges Danton. The Committee decreed that the army must first suppress the revolt. On 29 April, during the ensuing fight, the Jacobins lost control of the city of Marseilles. Lyons broke out into full-scale revolt with severe street fighting a month later. Bichat participated in this attempt on the part of royalists and moderates to overthrow the Jacobin municipal authorities. For a brief time they were successful.

On 2 June 1793, Jean-Paul Marat's supporters in Paris expelled the more moderate Girondin deputies from the Convention, leaving unquestioned political authority in Jacobin hands. The arrest of twenty-nine Girondin deputies precipitated another reaction outside the capital. In Lyons, Marseilles, and Toulon, Jacobins were guillotined or hanged. In July, part of the Alpine Army was ordered to march against Lyons, Bichat helped to prepare the city's defences. But when a decree ordered all persons who were not citizens to leave Lyons on pain of being considered conspirators, Bichat left to return home to Poncin.

On 1 August, the same day Bichat left Lyons, the Ministry of War began a requisition of all health officers, physicians, surgeons, and apothecaries between the ages of eighteen and forty years to be divided among the armies of the Republic. It was a time of grave crisis and there was little reference made to ability or training. Hospitals were designated as teaching centres in which the more qualified medical practitioners would instruct those who had not completed their formal training. Bichat was drafted and sent to Grenoble and then to Bourg to serve as a surgeon in the Department of the Ain whose hospitals were put under military control. Wounded soldiers from the troops besieging Lyons were sent there. At the end of 1793, the hospital was dissolved. Again, Bichat returned to Poncin.

At home, he found that the Revolution had provoked a predictable resentment against the bourgeois Bichat family. In the early stages of the Revolution, JeanBaptiste Bichat had been a deputy of the Third Estate. More recently, however, he was accused by the sansculottes of a lack of patriotism. It was a common enough accusation and a sufficiently vague one to be very widely applicable. The accusation also touched the sons of the family. In order to persuade their detractors that they were indeed patriotic, Xavier and César enrolled in work for military ambulances and voluntary battalions respectively. Because of the local pressures, Xavier left for Paris in June 1794. For a time, he lived with his uncle, aunt, and cousin Buisson, who had fled to the capital from Lyons during the siege. It was an invaluable move, for there Bichat gained access to the sort of professional and intellectual society which Paris

4 Vess, op cit., note 3 above, pp. 40-53. 


\section{Xavier Bichat}

traditionally drew to itself, and he was at last permitted to study seriously and to practise medicine.

When the Revolution started in 1789, there were eighteen medical schools in France, although only Paris and Montpellier enjoyed any particular reputation. There were also fifteen colleges of surgery and a college of pharmacy. Few physicians would have disputed the need for a reform of medical education, but the revolutionaries, especially the Girondists, were unwilling to permit the profession to reform itself. They exaggerated the abuses of many professions, accusing them in general of being the preserve often of charlatans. The Convention had already meddled in medical education in 1791, as we have seen. In 1793, its members went even further. On 28 August, the Convention abolished all literary academies, the Royal Academy of Medicine, and the Royal Academy of Surgery. On 15 September, all the university faculties in France were declared closed. ${ }^{5}$ Thus the revolutionary republicans had carried to its logical conclusion their conviction that the savants of the old regime and their aristocratic institutions were an affront to their Revolution's egalitarian goals. With the closure of these bastions of aristocracy, idealists hoped, as idealists will, that henceforth there would be no examinations and no qualifications other than age, experience, and respect for citizens. Whoever wished to teach mathematics, law, or medicine would have only to obtain from his municipality a certificate of integrity and good citizenship. It was assumed that freely given lessons would be largely paid for by the students. In the meantime, other persons persisted in wanting to resurrect a reformed system of education. Accordingly, the Convention urged the Committee of Public Education, of which the chemist Antoine Fourcroy was an important member, to hurry a report on a proposed reorganization of the system.

By the autumn of 1793 and throughout 1794, the only course of action open to men such as Bichat who were seeking medical instruction was to attach themselves to hospitals as apprentices. Desault, the founder of clinical teaching of surgery in France attracted many such private students, including Bichat, as well as those attached to hospitals. He had been a member of the Royal Academy of Surgery and, since 1786, Chief Surgeon of the Hôtel-Dieu. The position involved treatment of some 400 patients. In 1791, Desault was responsible for ninety non-resident surgical students or externes and for fourteen resident internes. In an amphitheatre he set up in 1788, he offered surgical demonstrations which were attended also by the private students. By 1791, Desault was providing daily anatomical dissection demonstrations before as many as 300 students. $^{6}$ In May 1793, just when the civil war crisis was developing, Desault was arrested and brought to trial before a Revolutionary Committee, charged

\footnotetext{
sTheodore Puschmann, A history of medical education, New York, Hafner, 1966, facsimile of 1891 edition, pp. 420-421. The institution of clinical hospital courses in surgery in Paris is discussed by Toby Gelfand, 'The hospice of the Paris College of Surgery (1774-1793); a unique and invaluable institution', Bull. Hist. Med., 1973, 47: 375-393. The attitudes towards hospitals and towards medical instruction during the revolutionary period are discussed in Michel Foucault, The birth of the clinic, trans. by A. M. Sheridan, London, Tavistock, 1973, pp. 38-53.

- Gelfand, op. cit., note 2 above, pp. 116-125, discusses Desault specifically. See also Toby Gelfand, 'A confrontation over clinical instruction at the Hôtel-Dieu of Paris during the French Revolution', J. Hist. Med., 1973, 28: 268-282. This article relates the circumstances of a complaint from a delegation of "citizen students of surgery" to the Committee of Public Instruction. Gelfand translates a letter from Desault to that Committee composed in November 1791. It relates a good deal about his teaching methods.
} 


\section{The life of a young physician}

with refusing aid to the wounded, but he was acquitted in August, due largely to the efforts of Antoine Fourcroy.

The Terror was at its height when Bichat arrived in Paris in June 1794. Though the Revolutionary Tribunal had already reaped a harvest of heads, executions multiplied after 10 June. That day, in order to destroy the Girondist Georges Danton, Robespierre induced the Tribunal to pass the Loi de prairial, which denied a defence at the trial of anyone accused of an offence against the state. On $28 \mathrm{July}$, the 9th of Thermidor according to the revolutionary calendar, the guillotine finally decapitated Robespierre himself and put an end thereby to the excessive Terror which had shaken France. Thereafter, many physicians and other citizens who had been suspended for disloyalty since September 1791 were recalled to active duty with the troops in the field. I have found no reference to political events in any extant work or letter composed by Bichat.' He assiduously avoided any direct political involvement, even though he was thrown into association with many intellectuals who were variously involved in the re-evaluation and reform of French institutions.

Bichat's natural abilities were reinforced by a remarkable capacity for hard work and self-discipline. Those qualities, along with a stroke of good luck, brought him to Desault's attention. One day, he offered to deliver a public lesson on the subject of a fractured clavicle when the student to whom the task had been assigned was absent. It must have been an impressive performance, for in a letter to his family dated 1 October 1794, he announced that he was living in Desault's home and that he planned to stay in Paris a long time. ${ }^{8}$ This arrangement permitted Bichat to complete his education in surgery and anatomy under the tutelage of France's pre-eminent surgeon. It must also have facilitated his social and professional contacts with persons whose ideas would help him to formulate his own notions of anatomy and physiology.

Formal medical training was re-established in France by a decree of 4 December 1794. A major stimulus to do so had apparently been provided in Antoine Fourcroy's report, which noted the death of more than 600 army health officers during the preceding eighteen months and the necessity for recruitment for the army health service. Medical schools were created in Paris, Montpellier, and Strasbourg.9 The ancient distinction between medicine and surgery was finally abolished for ever, and Desault

' Possibly Bichat avoided mentioning politics because to do so would have worried his family. The life of the elder Bichat as well as his reaction to the Revolution are' briefly discussed by Jean Rousset, 'Trois docteurs de Montpellier, pères de médecines célèbres nés dans la région Lyonnaise', Monsp. Hippoc., 1965, 8: 8-11.

- Letters from Bichat to his parents are quoted by Emile Jean Kervella in 'La vie et l'oeuvre de Bichat (1771-1802)', a thesis presented to the Paris Medical School for the Doctorat en Médecine in 1931. Among these letters are pleas to his family to understand that he is busy and therefore unable to come home. There are also requests for money.

The Paris Medical School was given twelve professorships: anatomy and physiology, pharmacy, medical physics and hygiene, surgical pathology, pathology of internal diseases, natural history, surgical operations, clinical surgery, clinical medicine, clinical convalescence, obstetrics, history of medicine and forensic medicine. Montpellier was given nine professorships, and Strasbourg six. Each professor was given an assistant. It seems that for a time, the schools were hampered by a shortage of qualified students and had to open their doors to citizens of the French colonies as well as to French nationals. See Puschmann, op. cit., note 5 above, p. 539; Vess, op. cit., note 3 above, pp. 153-184; and Gelfand, op. cit., note 2 above, pp. 149-171. For a discussion of the nature and consequences of the reformed medical education system, and for Bichat's contribution to the reform, see Foucault, op. cit., note 5 above; and Erwin H. Ackerknecht, Medicine at the Paris Hospital, 1794-1848, Baltimore, Md., Johns Hopkins University Press, 1967. 


\section{Xavier Bichat}

was named Professor of Clinical Surgery (clinique externe) in the Paris school. His hospital courses at the Hotel-Dieu became part of the new medical school. Curiously, he and other members of the College of Surgery disapproved of this marriage between the two branches of medical practice, even though it represented the end of a long and bitter battle to raise the professional status of surgery.

Desault died of a fever on 1 June 1795, amid rumours of poison, since he was treating the dying son of Louis XVI. Desault had lived just long enough to permit his special student to establish himself successfully in Paris. Bichat was twenty-four years old when Desault died. He continued to live for most of his remaining six years in the Desault apartment as a kind of adopted son of Madame Desault. We know little of his personal life. The quantity of work which he accomplished suggests that there must have been little time for anything else but the study of anatomy and physiology.

Bichat's training to this point had been primarily surgical, first in Lyons and then in Paris. For a while after Desault's death, his work predictably took its direction from his teacher. In January 1791, Desault had commenced work on a Journal de chirurgie, which appeared finally in September 1792. With the help of Corvisart, the holder of the chair of clinical medicine in the Paris Medical School, Bichat collected some of his teacher's unpublished manuscripts and completed a fourth and final volume of the journal in 1795. It included five articles by Bichat, dealing with surgical questions as well as a 'Notice historique sur Desault', his final and public tribute to his esteemed teacher. ${ }^{10}$

Meanwhile, the insecurity created by revolutionary excess was subsiding. On 22 March 1796, members of the former Academies of Medicine and of Surgery, along with other physicians, surgeons, chemists, and pharmacists, formed the Société de Santé de Paris, later renamed the Société de Médecine. Bichat was named a resident member in October 1799. It seems, however, to have been a somewhat stodgy society, and certain professional young men felt the need for another. Bichat was one of the principal founders of the Société Médicale d'Émulation, which met for the first time in the Medical School on 23 June 1796." It was seen to be a kind of successor to the Société Royale de Médecine, which, between 1788 and 1794, attracted to it France's most progressive physicians. "Émulation" is said to have been a word used by Félix Vicq d'Azyr, the perpetual secretary of the Société Royale, to mean professional standards. ${ }^{12}$ Clearly, the new group represented the opinions of the new medicine emerging in the post-revolutionary period. The Société d'Émulation's initial resident membership list included Alibert, Cabanis, Fourcroy, Pinel, and Corvisart, and among fifty corresponding members were the names of Bell, Barthez, and Spallanzani. In fact, so many of the most noteworthy members of the Parisian medical profession joined its ranks in its first few years that it became a virtual

\footnotetext{
10 Xavier Bichat, 'Eloge de P. J. Desault', Oeuvres chirurgicales de P. J. Desault, a new edition corrected and augmented by Bichat, 3 vols., Paris, Mequignon, 1801-03, vol. 1, p. 52.

1 The Société Médicale d'Emulation deserves more study that it has received so far, since its membership list included the names of many of France's most influential physicians. To date, one of the best studies of that society and especially of the views shared by its members concerning the nature of scientific medicine is found in Sergio Moravia, 'Philosophie et médecine en France à la fin du XVIII' siècle', Studies on Voltaire and the eighteenth century, 1972, 89: 1089-1151.

${ }^{12}$ Gillispie, op. cit., note 3 above, p. 222.
} 


\section{The life of a young physician}

"Who's Who" of European medicine.

In July 1799, Bichat was invited to join the Société Philomathique de Paris, founded in 1788 to promote its members' knowledge of all the natural sciences. ${ }^{13}$ In 1800 , he acted as a secretary to the Société de l'École de Médecine de Paris, which was created by the government to provide expert consultants on all questions of health, disease, hygiene, and medical services. His enthusiasm was, nevertheless, always reserved primarily for the Société d'Émulation.

In 1797, Bichat undertook to teach a private anatomy course in a laboratory at 18 rue des Carmes on the Left Bank. His classes appear to have been very successful, this first one attracting nearly eighty students. This sort of teaching, existing alongside that offered by the Medical School, was common at the time. Private teachers, however, faced special problems, for, unlike the Paris Medical School which, in 1795, had 500 cadavers placed at its disposal, they had no access to anatomical material. Bichat resorted to raiding cemeteries. He was arrested in Saint Catherine's cemetery during one such midnight venture, but escaped with a reprimand. The government finally ordered that bodies be made available to dissection laboratories in September 1798. A letter dated 29 November of that year from the Office of Public Health and Welfare authorized Bichat to bury human debris resulting from such dissection. Bichat's teaching operation was expanded in September 1801, when he installed himself at the Collège de Liseaux, also on the rue des Carmes. He both lived and worked in the large apartment for the last ten months of his life.

Bichat directed publication of a collection of Desault's surgical works, which appeared in 1798. Thereafter, his direct involvement with surgery began to give way to an interest in questions of a specifically anatomical and physiological nature. In the second volume of the Mémoires de la Société Médicale d'Émulation there are six articles written by Bichat. Three of them deal with surgical topics, but the others provide a preview of the physiological and anatomical work which he was to do thereafter. The first surgical paper was concerned with some modifications of the process of trepanning; the second dealt with fracture of the clavicle, that same lucky bone which had initially brought him to Desault's attention; the third related a new method for ligaturing polyps. ${ }^{14}$

The fourth paper demonstrated that there is a specific organ which actively produces the synovial fluid which lubricates the body joints and articulation. ${ }^{15}$ Bichat intended that it be read along with the next paper, in which he divided the bodily membranes into six distinct varieties. He examined their properties and characteristics, treating each one as an anatomical entity in its own right, a specific organic structure which is part of the compound arrangement of organs. ${ }^{16} \mathrm{~A}$ book entitled the Traite des membranes, published early in 1800 , developed at length the ideas first discussed in these two articles.

Bichat's third article in the 1798 Mémoires presented a theory which he made the

13 Ibid., pp. 193-194.

14 Xavier Bichat, 'Description d'un nouveau trépan', Mémoires de la Société Médicale d'Enıulation, 1798, 2: 277-282; 'Mémoire sur la fracture de l'extrémité scapulaire de la clavicule', ibid., 309-322; 'Description d'un procédé nouveau pour la ligature des polypes', ibid., 333-338.

15 Bichat, 'Mémoire sur la membrane synoviale des articulations', ibid., 351-370.

${ }^{16}$ Bichat, 'Dissertation sur les membranes, et sur leurs rapports généraux d'organisation', ibid., 371-385. 


\section{Xavier Bichat}

basis for all his subsequent assumptions concerning vital functions. He had discovered, he asserted, that animal nature breaks down into two essentially distinct "lives". The more basic or organic life, which is common to both the plant and animal kingdoms, functions primarily to nourish an animal and to maintain its existence apart from the inert and inorganic world that surrounds it. With its higher or animal life, a creature becomes conscious and develops a relationship with objects external to it. ${ }^{17}$ This notion, in turn, was incorporated as a major theme in one of Bichat's books, the Recherches physiologiques sur la vie et la mort, which was ready for sale in May 1800.

In La vie et la mort, Bichat elaborated his theory on the nature of living matter. He opened the work with his now famous definition of life as "the totality of those functions which resist death". However inadequate that may seem to be from the viewpoint of the modern philosopher of science, the meaning of those words seemed clear enough to most of Bichat's readers at the turn of the century. At the root of Bichat's vitalist notions was the assumption that nature is in every respect divided into two great realms, living bodies being subject to laws and principles different from those of the physical realm. Bichat presented his investigation of the former realm in La vie et la mort. He stated what he considered some of those laws and principles to be. At the same time, he determined that living matter possesses five vital properties which derive from the animal's ability to perceive and to move, from its sensibility and contractility.

Bichat wrote modestly to his parents that his new work had met with some success. ${ }^{18}$ Such evidence as there is suggests that he was already recognized as an eminent member of the medical community even before he had any sort of official position. A Leiden physician named Sandifort paid him a considerable compliment when he wrote to Hallé in Paris that "In six years, your Bichat will have surpassed our Boerhaave." 19 There were, however, the inevitable detractors also. A young professor of anatomy and physiology who did work similar to Bichat's and who might have been his rival as the rising star of Paris medicine once accused Bichat of being "a vile plagiarist". ${ }^{20}$ Possibly with some justification, Richerand claimed priority for himself and for others for some of the ideas expressed in La vie et la mort. ${ }^{21}$ As we shall see later, a great many of Bichat's ideas were borrowed from a variety of medical men. No one works in isolation, of course, but part of the problem was that Bichat rarely acknowledged his intellectual debts. This would not, in fact, be the only occasion on which such a charge would be levelled at him, though not again with such vehemence. Bichat's failing was common enough in the eighteenth century. In any case, he freely

\footnotetext{
${ }^{17}$ Bichat, 'Mémoire sur les rapports qui existent entre les organes à forme symmétrique el ceux à forme irrégulière', ibid, 477-487.

${ }^{18}$ Quoted by Genty (1933), op. cit., note 1 above.

19 Buisson, op. cit., note 1 above.

${ }^{20}$ Anthelme Richerand, 'Réflexions critiques sur un ouvrage ayant pour titre: Traité des membranes', Magasin encyclopédique, 1800, 6: 260-272. Othmar Keel, 'Les conditions de la décomposition "Analytique" de l'organisme: Haller, Hunter, Bichat', Études Philosophiques, 1982, no. 1, 37-62, refers to this denunciation, claiming that Richerand knew that Bichat's notion of membranes was lifted without acknowledgement from one A. Bonn.

${ }^{21}$ Anthelme Richerand, 'Essai sur la connexion de la vie avec la circulation', Décade philosophique, 29 June 1800.
} 


\section{The life of a young physician}

incorporated a multitude of ideas which were floating about at the time concerning the nature of life and its functions and he combined them into a unique and coherent system of physiology. He believed that in so doing he was creating an innovative and sound theory into which all future observations and experiments made by medical scientists would be integrated. Many people were subsequently to agree with his own evaluation of his work.

In the winter of 1799 , Bichat had to obtain corpses from the guillotine to supplement an inadequate supply. To do certain experiments on the subject of violent death, he arranged to have access to bodies immediately after their execution. The grisly observations he made on them provided him with the material for the second part of La vie et la mort.

That same winter, Bichat stopped attending the meetings of most of his medical and scientific societies, pleading overwork. The government, nevertheless, expected him to continue to do his patriotic duty. The municipal authorities named him to examine conscripted citizens who asked for exemptions from army service for reasons of health. For France, this was a period of protracted military involvement throughout Europe and in Egypt, and it seems that there were plenty of draft dodgers. Bichat was also bothered by pressure from his parents to return home to Poncin. ${ }^{22} \mathrm{He}$ did not yield to it, and, in fact, he never saw his parents again after he left Poncin for Paris in 1794.

Meanwhile, Bichat did not yet possess a single official title or degree. In a letter to the Minister of the Interior, he requested a position as médecin surnumeraire at the Hôtel-Dieu. The administrative commission of hospitals, however, awarded him the lower rank of médecin expectant at that institution in January 1801. Though it was less than he had hoped for, it gave Bichat the opportunity to visit patients in hospital, one of his favourite occupations, according to the eulogy of him which was delivered before the Société Médicale d'Émulation. ${ }^{23}$ In February, Bichat offered himself as a candidate for a recently vacated chair of anatomy and physiology at the Medical School. That position went to a physician named Duméril, who was already at the school, and Bichat had to content himself with private teaching and experimentation. ${ }^{24}$

Bichat's major work was a four-volume Anatomie générale appliquée à la physiologie et à la médecine, which went on sale in August 1801. In it, one finds all the assumptions of his vitalist thesis serving as a substructure for an elaborate anatomical analysis of living matter. Bichat presented here his tissue theory of anatomy to the medical world. In many respects, it was an extension of the Traite des membranes, for in it, he lists the membranes previously examined among the twenty-one elements of the body. Though Bichat had borrowed many notions from his fellow physicians in order to produce this work, the tissue theory as a whole was unique and innovative,

\footnotetext{
${ }^{22} \mathrm{~A}$ letter from Bichat to his parents is quoted by Kervella in op cit., note 1 above, pp. 50-53. In it he was pleading for understanding from his parents. He mailed them a copy of the Traite des membranes at the same time; he had dedicated the work to his father.

${ }^{23}$ A. F. T. Levacher de la Feutrie, 'Eloge de Marie-François-Xavier Bichat', Mémoires de la Société Médicale d'Emulation, 1803, 5: xxvii-Ixiv. This eulogy is fairly typical of its time in so far as it abounds in flattery but is deficient in details and analysis.

${ }^{24}$ The letters are quoted by Genty (1934-35), op. cit., note I above, pp. 181-182.
} 


\section{Xavier Bichat}

although it was seen by many persons, with considerable justification, to be a kind of echo in the life sciences of Antoine Lavoisier's work in chemistry two decades earlier. Lavoisier had composed a list of the material elements which make up the compounds that preoccupy the chemist and the physicist. The great variety of these compounds, he claimed, is merely the consequence of the proportions and arrangement of these elements.

Bichat examined the unique physical and vital properties of each tissue. The details of that work were altered significantly by Bichat's successors in the next century. Its vitalist underpinnings were discarded by most physiologists within a few decades. Nevertheless, the concept basic to the tissue theory has always been conceded to be sound, thereby ensuring that Bichat has retained a place of some importance in medical history.

The arguments which Bichat presented on behalf of the tissue theory were based upon a remarkably large number of experiments and observations. In these busy years, Bichat was assisted by his cousin Buisson and by a lively young student named Philibert-Joseph Roux. Roux joined Bichat's course at the anatomical theatre when it first opened in 1798. Bichat took a liking to the bright young man, who remained with him for the last four years of Bichat's life. Though Buisson was a conscientious worker, it seems that he was too pious and even puritanical to be an attractive or comfortable companion. Roux, on the other hand, succeeded in interesting his ascetic young mentor in the theatre, which they attended night after night. This diversion for the formerly single-minded Bichat was a bit of a problem for his publisher, who was driven to charge a young apprentice named Chaudé with the task of claiming the manuscript of Anatomie générale page by page. Chaudé reported that Bichat lived amidst his anatomical specimens and their debris to such an extent that it was difficult to separate the various bits on his table into lunch and experiment. When pressured for text, he used merely to compose parts of his book on whatever bits of paper fell to hand. ${ }^{25}$ It emerged, as we shall see later, with major inconsistencies in it, perhaps as a result of this pressure.

Buisson and Roux completed Bichat's final published work after his death. The Traite d'anatomie descriptive was a synthesis of his vitalist theories and of his tissue work. In the preliminary discourse to the book, Bichat related that the object of the Anatomie générale had been to decompose the body into its parts, whereas that of the Anatomie descriptive was to reverse the process so as to discuss the combinations of those parts into organs, systems, and functions. In this five-volume work he set out to examine the body system by system, studying the apparatus of locomotion, voice, sensation, digestion, respiration, and so on. Death interrupted the work when he was in the middle of the third volume. Buisson completed it and composed volume four, while Roux did the final one.

In his last winter, Bichat taught a course in pathological anatomy at the HôtelDieu. We have a record of his lectures in the form of notes taken by one of his students. They demonstrate quite clearly that Bichat's object was to extend the

\footnotetext{
${ }^{25}$ This is related by Blanchard, op. cit., note 1 above, pp. 16-25. Blanchard heard the story from an aged hospital surgeon, who had been a friend of Chaudé many years before.
} 


\section{The life of a young physician}

principles of his vital theory and his notion of tissues to include the study of pathology. ${ }^{26}$ That winter, Bichat continued to do dissections, to practise vivisection, and to teach about eighty students. Genty lists many student dissertations that took their point of departure from the therapeutic principles of Bichat. ${ }^{27}$ According to Buisson, he opened more than 600 cadavers in his last year. He had the temerity to work amidst odours that drove away even his most dedicated students. Just before he died, Bichat was considering a new edition of La vie et la mort; he had begun a series of experiments which grew out of La vie et la mort and had to do with the chemical phenomena of respiration; with a colleague he was performing experiments on galvanism. He began to teach a formal course in materia medica in May 1802 . He reportedly sought for the basis of pharmacological action of drugs in their effect on the five vital properties, assuming that illness was the consequence of the deviation of these properties from some normal state.

Bichat fainted while descending a set of stairs in the Hôtel-Dieu on 8 July 1802. The cause of his illness is not clear. He had suffered from gastric trouble and from jaundice since the beginning of 1801 , and his final illness could have been a development of some problem associated with those symptoms. On the other hand, it is possible that he was infected with some contagious fever while examining skin putrefaction in a corpse. His fellow physicians were thrown back on to their traditional treatments. Bichat was given emetics and bled by the application of leeches. A merciful coma released him from the ministrations of contemporary medical practice a few days before he died on 22 June.

Bichat's death came at the end of an important era in medical history. He had lived largely in the eighteenth century, a time that Lester King has described as "the adolescence of present day medicine". ${ }^{28}$ It was then that the science of physiology, the specific discipline which deals with the functions and processes of living organisms, was developed. In that hundred or so years, many fundamental problems important to the subsequent development of medical and life science were identified and examined. Bichat's work belongs to that time and fits squarely into its methods and assumptions. For example, all of Bichat's observations and theories were designed so as to fit his vitalist theory. It was his consistent guide in his speculation and his experimentation. Always, he treated the vital properties as the link connecting all the branches of medicine. Bichat's ideas concerning life, its separation from non-life, and its unique vital properties became part of the theoretical and intellectual stock-intrade of physicians. His reputation for at least the first two decades of the nineteenth century were very high. It was Magendie, a member of the Paris Medical Faculty, who first discussed Bichat's vital theory with a view to demonstrating that it must be

\footnotetext{
${ }^{26}$ Xavier Bichat, Anatomie pathologique, Paris, Baillière, 1825. A recently discovered manuscript in the Bibliothèque de l'École de Médecine de Grenoble is reported to be a richer version of these lectures than Beclard's manuscript. It is discussed by Jean Monteil in 'Le cours d'anatomie pathologique de Bichat: un nouveau manuscript', Presse méd., 1964, 72: 3163-3166.

${ }^{27}$ A complete bibliography of Xavier Bichat has been compiled by Geneviève Nicole-Genty, 'Bibliographie', in Genty (1972), op. cit., note 1 above, pp. 296-317. This is broken down into 'Oeuvres de Bichat', 'Travaux sur Bichat', 'Manuscrits de Bichat', 'Iconographie', and a 'Chronologie de Bichat et de son époque'.

${ }^{28}$ Lester S. King, The medical world of the eighteenth century, University of Chicago Press, 1958, p. xvi.
} 


\section{Xavier Bichat}

abandoned in order that physiology and its cognate sciences be established upon physical and chemical foundations. ${ }^{29}$ Much of Magendie's work, and especially that of his student Bernard, was designed to show that physiology is as deterministic as physics.

Bichat was persuaded that vitalist notions of the living body were correct for reasons very much like those articulated by physicians who had received their medical training at Montpellier. By the middle of the eighteenth century, most lecturers at that school had rejected iatromechanism, the popularly held notion which maintained that the body is fundamentally an intricate and elaborate machine. Bichat was familiar with their work. Many of them, as well as persons from other European medical schools, devoted a considerable amount of time and energy to studying the sensibility and contractility of living matter. The observation and analysis of an organism's sensation and motion contributed enormously to the progress of physiological theory. Bichat created his influential physiological system from an amalgam of pro-vitalist convictions and notions concerning the reactivity of the bodily parts. We shall examine a few of these major currents in eighteenth-century physiology and their influence on Bichat's work in the remainder of this book.

\footnotetext{
${ }^{29}$ François Magendie, An elementary compendium of physiology, trans. with notes by E. Milligan, Edinburgh, John Carfrae, 1823, pp. 10-14.
} 